\title{
The impact of extreme weather events on community risk planning and management: the case of San Juan, Puerto Rico after hurricane Maria
}

\author{
O impacto de eventos climáticos extremos no planejamento e no \\ gerenciamento de riscos comunitários: o caso de San Juan, Porto Rico, após o \\ furacão Maria
}

Luis Santiago[a], David Flores[b], Chang-Yu Hong $[c][$

\author{
[a] University of Central Florida, School of Public Administration, Orlando, Florida, USA \\ [b] USDA Forest Service, Fort Collins, Colorado, USA \\ [c] Jeju Research Institute, Jeju-do, Republic of Korea
}

How to cite: Santiago, L., Flores, D., \& Hong, C.-Y. (2020). The impact of extreme weather events on community risk planning and management: the case of San Juan, Puerto Rico after hurricane Maria. urbe. Revista Brasileira de Gestão Urbana, 12, e20190062. https://doi.org/10.1590/2175-3369.012.e20190062

\begin{abstract}
Top-down technical or engineered solutions to deal with flood control such as channelization are increasingly unaffordable. We explored how community leaders' frame the concept of risk, particularly due to flooding, and documented bottom-up rather than top-down solutions within the context of Hurricane Maria and the current financial crisis. This research aimed to interview environmental conservation organizational leaders to assess the broader question of what makes San Juan livable, and the role that flooding risk management plays in defining livability. Their perception of bottom-up approaches for flood control, including the role of green infrastructure, is of particular interest given the infeasibility of current engineered measures and their history of short term local coping strategies. Our research team frames the research using structural versus non-structural solutions to explore to what extent community leaders draw upon green visions of the city or emphasize transitioning towards strategies more closely aligned with ecological processes and functions. The research results help to inform current efforts of local community engagement about alternative solutions to channelization and other urban flood management measures.
\end{abstract}

Keywords: Community risk planning. City livability. Community-based flood control. Perception assessment.

\section{Resumo}

Soluções técnicas que são projetadas de cima para baixo (top-down) para lidar com o controle de enchentes, como a canalização, são cada vez mais inacessíveis. Neste trabalho, explorou-se como os líderes comunitários enquadram o conceito de risco, particularmente devido a inundações, e documentamos soluções de baixo para cima (bottom-up), em vez de soluções de cima para baixo, no contexto do furacão Maria e da atual crise financeira. Esta pesquisa visou entrevistar líderes organizacionais de conservação ambiental para avaliar a questão mais ampla do que torna San Juan habitável, e o papel que o

LS is a doctor in Urban and Regional Planning and Associate Professor, e-mail: luis.santiago2@ucf.edu

DF is a doctor in Sociology and Research Social Scientist, e-mail: davidflores@fs.fed.us

CYH is is a doctor in Urban Studies and Planning and Research Scientist, e-mail: 503changyu@gmail.com 
gerenciamento de risco de inundação desempenha na definição da habitabilidade. Na percepção dos líderes, abordagens ascendentes para o controle de enchentes, incluindo o papel da infraestrutura verde, é de particular interesse, dada a inviabilidade das atuais medidas de engenharia e do histórico de estratégias de enfrentamento local de curto prazo. A equipe responsável enquadra a pesquisa usando soluções estruturais em contraste com soluções não-estruturais para explorar até que ponto os líderes comunitários se baseiam em visões verdes da cidade ou enfatizam a transição para estratégias mais alinhadas com processos e funções ecológicas. Os resultados da pesquisa podem ajudar a informar os esforços atuais para envolver as comunidades em nível local sobre soluções alternativas para canalização e outras medidas de gerenciamento de enchentes urbanas.

Palavras-chave: Planejamento de risco comunitário. Habitabilidade da cidade. Controle de inundação baseado na comunidade. Avaliação de percepção.

\section{Introduction}

A proposal by the US Army Corps of Engineers to channelize sections of the Rio Piedras watershed in San Juan, Puerto Rico has shed light on alternative risk management strategies. Structural solutions to deal with flood control such as channelization are increasingly infeasible (Di Baldassarre et al., 2015; Konrad, 2016; Hong \& Chung, 2016), and the institutions that have traditionally carried out projects of that magnitude are increasingly unable or unwilling to finance projects of that magnitude (Shan et al., 2017). Given that new reality, community-based non-governmental organizations and community leaders and residents began to shoulder the burden of responsibility for increasing flood risk (Razafindrabe et al., 2014). Our interest is to explore how environmental conservation organizational leaders frame the concept of risk due to flooding, as well as solutions within the context of the current public sector financial crisis and hurricane recovery. The Rio Piedras watershed, our study area, is of particular interest given its high population density and its history of interventions that led to the burial of river segments with cement canals.

Before Hurricane Maria hit the island of Puerto Rico on September 20, 2017, we were in the process of conducting in-depth interviews with organizational leaders to assess the broader narrative of what makes San Juan livable, centering on the role that flooding risk management plays in defining livability. Their perceptions of bottom-up approaches for flood control, including the role of green infrastructure, is of particular interest given the infeasibility of current engineered measures and a history of short-term government coping strategies. We frame the research using structural versus non-structural solutions to flood risk to explore to what extent community leaders adhere to traditional built approaches or advocate transitioning towards strategies more closely aligned with ecological processes and functions, which in the long run may be more feasible. The strategy shift would essentially represent a departure from static, present-day, livable city ideals to dynamic, future-oriented livable/sustainable city point of view. Finally, we set out to explore institutional and procedural considerations associated with an implementation of proposed community approaches to managing flood risk.

The set of data was gathered by means of in-person interviews with environmental conservation organizational leaders in the San Juan, Puerto Rico area; prior to Hurricane Maria, we had conducted nineteen interviews, and in January of 2018 resumed interviews with an additional four organizational leaders. Exploratory research results will help inform current efforts on how best to engage communities in thinking about alternative more dynamic bottom-up solutions to channelization and other urban flood management measures within the context of recovering from a devastating hurricane. The documentation of bottom-up, ecologically sensitive dynamic approaches could become a key component of flood control management strategies given the high state of vulnerability experienced in the Island as a result of natural disasters, financial instability, high emigration flows, and a rapidly aging population. 


\section{Literature review}

Our aim is to explore how flood risk is framed from the point of view of the community organizer. In many countries, there has been a paradigm shift to more distributed flood risk management strategies, where responsibilities have been devolved to the local levels (McEwen et al., 2017). We also want to explore how their framing of flood risk intersects with the concept of city livability, whether organizers' proposed solutions to flood risk adhere to structural or non-structural (natural or nature-based features) parameters (Sun et al., 2012), and what are some of the institutional and procedural considerations (Gersonius et al., 2016) required for their proposed interventions to deal with local flood risk management (Birkholz et al., 2014).

Risk has been defined as the intersection between a hazard, the exposure of people, assets to that hazard, and the vulnerability of people and assets that are exposed (Crichton, 1999 apud Schneiderbauer \& Ehrlich, 2004). Flood risk can be defined as the probability of negative consequences due to floods (ISDR, 2002; Bogdan et al., 2018). Rather than risk being isolated to single events such as hurricanes, risk is also rooted and reproduced in common social and institutional sources such as governing bodies, organizations, and groups that tend to push for economic growth (Tierney, 2014).

Given the increasing infeasibility of engineered solutions (Low, 2013; Tullos, 2018) for flood risk management, proposed community solutions (Jukrkorn et al., 2014) to flood risk will be classified according to engineered (structural) versus ecology-based (non-structural) solutions (Slovic, 1987; Kryzanowski et al., 2014). In recent years, the US Army Corps of Engineers have begun studying the possibility of implementing non-structural solutions, i.e., those that don't make use of traditional structural flood defense measures (USACE, 2017). Non-structural solutions can include natural or naturebased features. Natural features are created through an interaction of physical, biological, geologic and chemical processes operating in nature (Reinhardt et al., 2010). Nature-based features are created by human design (Sutton-Grier et al., 2018), in concert with natural processes, to provide essential ecosystem services (Liquete et al., 2015). These features require maintenance through human intervention (USACE, 2015).

Flood risk will be explored as one of several factors that affect city livability and sustainability (James, 2012; Hong \& Chung, 2016). Both concepts are particularly important in framing the concept of flood risk, given their prevalent use in the planning profession (Ruth \& Franklin, 2014). In contrast to sustainability, in the urban planning literature, livability has traditionally emphasized the livable city as a place for consumption (Holden, 2006; Conger, 2015). For example, Jacobs (1961) had a significant impact on initial concepts of livability, highlighting sidewalks as well as active retail spaces mixed with dense residential places. Wheeler (2001) described a livable city in broader terms, considering healthy environments, decent housing, safe public spaces, uncongested roads, parks and recreational opportunities and vibrant social interaction. Balsas (2004) and Garau \& Pavan (2018) gathered a group of key performance indicators to measure livability at an urban city center, identifying a group of measures that emphasized reinvestment and retail activity, but also considering housing, rising population and employment opportunities. Silverstein et al. (2008) defined livability in the context of an aging urban population as the features of a local community that support residents such as culturally appropriate services, good transportation options for non-drivers, safe neighborhoods and affordable housing. Their concept also encompassed valuing and respect for residents (Perkins, 2008).

The previous traditional definitions of livability have something in common: an explicit exclusion of risk, particularly due to flooding (Uehara, 2017). This is of concern especially in low-income regions that experience natural disasters such as Puerto Rico where Hurricane Maria devastated several communities across the island. Low-income populations historically perceive, prepare for, and respond differently to natural hazard risk, and are more vulnerable than higher social classes when it comes to emergency response, recovery, and reconstruction (Fothergill \& Peek, 2004). Thus, we explore whether community leaders' definitions of livability similarly exclude or include definitions of flood risk due to various factors such as climate change (CPE, 2015). 
Livability tends to be presented as a static concept, it addresses present problems with standard solutions (Hankins \& Powers, 2009; Kashef, 2016). It seems to be more immediately tangible and achievable (Ruth \& Franklin, 2014; Gough, 2015). In contrast, sustainability is usually considered a long run proposition with a global perspective, with consideration to environmental assimilation, and desiring fair and just social and economic development (Ruth \& Franklin, 2014). Time and scale components seem to be often overlooked when speaking of livability, so the sustainability concept can assist in capturing those dynamic elements necessary for appropriate management when facing increasing climate risk, such as the impacts of urban flooding and hurricanes in Eastern coastal cities (Ayyub \& Wright, 2016).

\section{Methods}

Semi-structured in-person interviews were conducted in the San Juan Bay Estuary area, located in northeastern Puerto Rico (see Figure 1) to assess environmental leaders' perceptions of flood risk, to explore the broader idea of what makes the city livable, and the role that flooding risk management plays in defining livability at the community level. Since the scope of our work focused on bottom-up perceptions of community risk and management frames, all interviewed leaders represented the nongovernmental sector. The work is exploratory in nature and our convenience sample was obtained from existing environmental and community networks in the area.

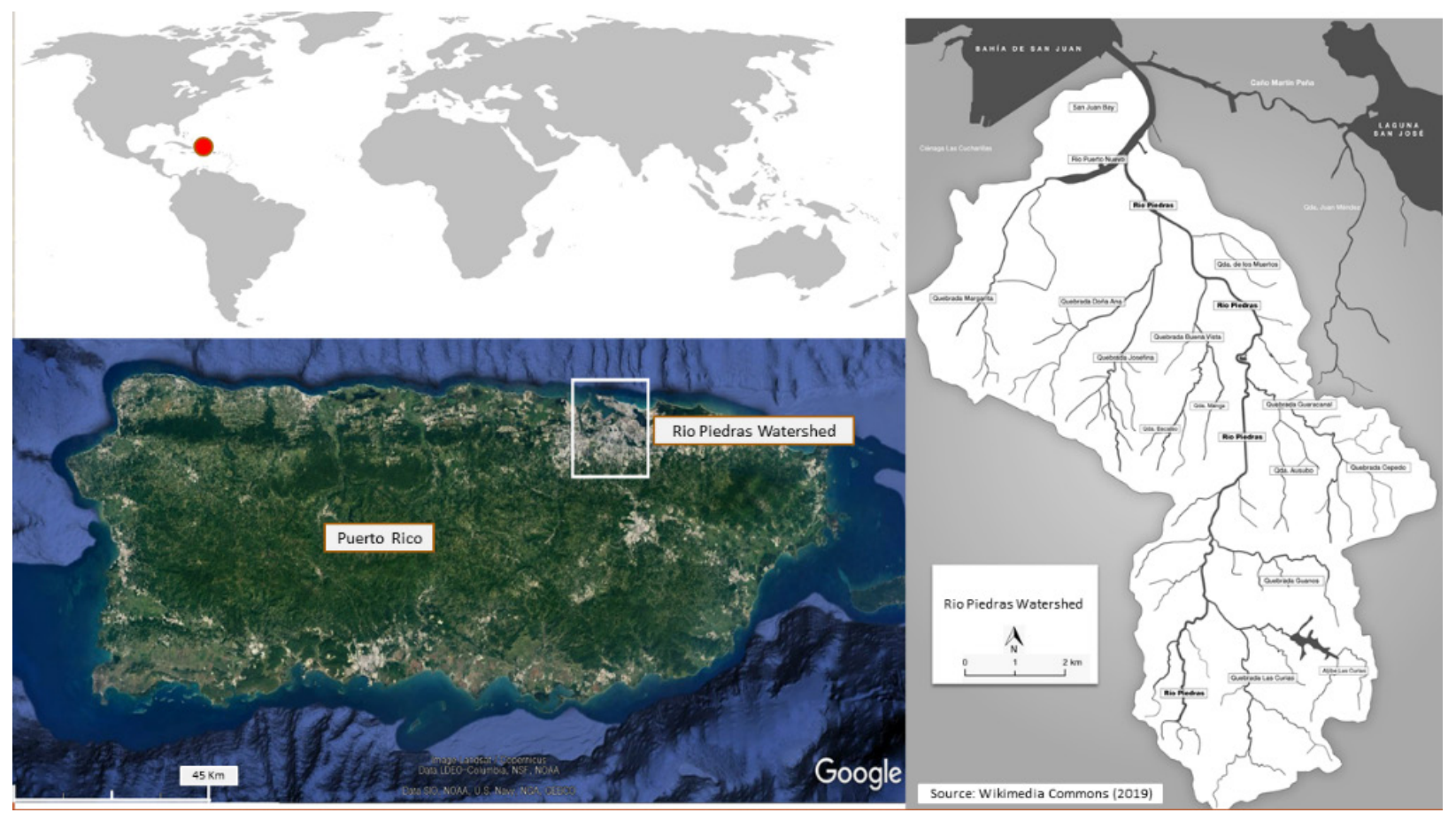

Figure 1 - Research Area: Rio Piedras Watershed.

The original project goal was to conduct thirty interviews; nineteen were completed before Hurricane Maria hit Puerto Rico. Interviews were conducted in Spanish, the participants' native language, and recorded for later transcription analysis. Our inability to meet the original goal of thirty interviews was a result of the hurricane; its devastating impact on infrastructure and the personal lives of community members made the process of continuing interviews extremely difficult, so only four interviews were completed following the extreme weather event. At its peak, Hurricane Maria reached a rating of category 5 with wind speeds of up to $175 \mathrm{mph}$. Its strength was reduced to a category 4 hurricane after crossing the island of Dominica and striking the island of Puerto Rico, dropping up to nearly 38 inches of rainfall, and resulting in severe flooding and mudslides across the island (Pasch et al., 2018). Phone and internet 
services were down across the island making it nearly impossible to contact interview participants following the hurricane. The students on the research team were also heavily impacted by the hurricane and the University of Puerto Rico was completely shut down. When classes did continue, much of Puerto Rico remained without power, phone, and internet services. Finally, when we were able to contact interview participants, we found them overwhelmed with helping communities recover from the hurricane, so several did not have time to participate in an interview. One potential interview participant requested one week of "sweat equity" from a student in order to grant an interview. In the end, funding for the project expired and the research team decided to move forward with the analysis of 23 total interviews.

Participating community organizations were selected in consultation with social science researchers who have conducted previous community work in the area of sustainability (Muñoz-Erickson, 2014a; Muñoz-Erickson et al., 2014; Santiago et al., 2015) . The organizations selected for this study work directly with environmental issues and are the most prominent environmental conservation organizations within the city of San Juan. While some organizations are highly structured, other organizations are less hierarchical and share leadership. For example, ENLACE del Caño Martín Peña and the Sierra Club of Puerto Rico are highly structured environmental conservation organizations. Other organizations such as Huerto Semilla (Seed Garden) and Playas Pa'l Pueblo (Beaches for the People) are less hierarchical and also consist of a significant number of college students. Nonetheless, all of the community organizations in this study work directly with issues of environmental justice and management throughout the city of San Juan. The interview participants for this study come from 16 environmental conservation organizations .

The research team contacted participants via phone and email in order to set up appointments. In some cases, such as with Playas Pa'l Pueblo, researchers needed to make physical contact with participants in order to request and interview. The interview question guide was prepared incorporating questions from a previous study conducted by the US National Science Foundation funded project San Juan ULTRA-Ex (Urban Long Term Research Area, Exploratory) and other sources (Muñoz-Erickson, 2014b; Muñoz-Erickson et al., 2016; Meléndez-Ackerman et al., 2016). The question guide contains five main sections: background questions on the individual being interviewed and the organization she represents, access to information on community environmental risks, their attitudes toward current livability in San Juan, the perceived capacity for community innovation and change, and a closing section that provides participants the opportunity to add anything to the interview that was not previously covered.

Interviews took place at the community organizer's office or in the field and consisted of approximately 1 hour, were tape recorded, and later transcribed for analysis. The analysis consists of thematic coding (Joffe \& Yardley, 2004) that draws upon previous studies of urban planning and environmental sustainability in San Juan. Once codes were identified, research team members individually coded the data and compared themes to identify reliable findings in the data.

The following findings are based on dominant narratives that framed the discussions around flooding risk, its role in defining livability, its management at the community and regional levels, whether the proposed management solutions were structural or non-structural, and institutional and procedural considerations necessary for their implementation.

\section{Framing the concept of flood risk}

Flood risk was mainly perceived through the lens of the particular organization's goals. While all of the organizations in this study emphasize environmental conservation, each organization defines flood risk within the framework of the respective organizational mission, vision, and goals. This in itself is not surprising, but when flood risk perspectives are examined as a whole, a cohesive overarching narrative emerges. The dominant narratives through which community leaders define flood risk and provide 
bottom-up solutions center on three general concepts: coastal impacts, drought, and access to relevant information.

\section{Coastal erosion}

Coastal erosion is perceived as a determinant of coastal flood risk. For organization leaders, sea level rise is not an abstract concept associated with climate change. Instead, it represents real shifts in land use that organizational leaders are adapting to on a daily basis in order to mitigate the impact on communities living along ocean fronts. Moreover, in Puerto Rico, with its mountainous interior, rivers flow from mountain tops, through cities, to coastal regions gathering pollution from sewer water that flows into communities, creating downstream flood and health issues. Organizational leaders that advocate for environmental protection of coastal areas, view their organizations as positioned at the forefront of climate change and urban development. Hurricanes were also mentioned as a source of concern, but prior to Hurricane Maria, were discussed in more abstract terms, and occasionally in comparison to the impact of Hurricane Hugo in 1989. Solutions to foster resilience and decrease flood risk due to coastal erosion were generally aligned to the organization's goals. For example, organizational leaders that support coastal areas advocate the restoration of sand dunes, both natural and artificial, as a means to build a more resilient coast that can withstand hurricanes and flooding events. One organizational leader described the conflict between urban development and the natural development of sand dunes by stating:

Here in the past there were large sand dunes. Those sand dunes prevented the ocean water from flooding this area. Those sand dunes disappeared because they used them to help build the airport. But now they are reforming because now we are taking care of this area... the dunes form because the wind moves the sand, the sand is stopped by the vegetation, and creates the sand dunes. (Playas Pa'l Pueblo).

He went on to describe other challenges associated with coastal erosion, emphasizing natural vegetation restoration as an easier and more cost effective alternative to engineered structural development. Similarly, other organizations that were inclined to rely on a more scientific approach to flood control argue that in San Juan structural solutions to flood mitigation have overlooked the benefits that the natural environment provides. As one interviewee described:

We need to be careful as humans that we do not put at risk the natural services that mother nature provides us which are essential. For example, water, for a long time people believed mangroves were a problem because they attract mosquitos, smell to areas, floods, disease, but once you begin studying them you begin to understand how the natural ecosystem functions, they are incredibly valuable for first, protection from hurricanes, second, purification of water, and third, it's a center that creates habitat for small fish. So something that looks like a problem turns out to provide an important function for a greater ecosystem. (Coop Madre Tierra).

How to mitigate coastal erosion is intimately connected to flooding along San Juan's coastline. Much of San Juan's coastal areas are currently occupied by grey infrastructure (buildings, roads, concrete, etc.), in place of natural areas such as mangroves. Organizational leaders have suggested replacing current abandoned buildings and empty lots as a result of the current economic crisis with natural green areas that are both ecologically beneficial and aesthetically pleasing.

\section{Drought}

In contrast to flooding, significant drought events are identified as an important source of risk and organizational leaders tied drought directly to drastic temperature changes that impact gardens and harvest yields. In San Juan, in particular, organizational leaders argue that drought impacts are most 
severe in the city centers where urban gardens are being developed and where grey infrastructure increase temperatures in the city's most vulnerable communities. On the one hand, vulnerable communities quickly become victims of flooding events when impacted by heavy rains and hurricanes due to impervious surface cover. On the other hand, recent droughts have left residents vulnerable to limited drinking water, and organizational leaders drew on their experiences helping communities overcome a major drought in 2015. That significant event led to organizational leaders making recommendations to the Puerto Rico Aqueduct and Sewer Authority, which supplies most of the water consumed in the San Juan Metropolitan Area. One community leader described to us how San Juan aqueducts now serve as their primary source for irrigation, and how access to aqueduct water is threatened during severe droughts:

One of the worries that we have related to climate change is during periods of drought in the city, since we are a garden in the city and when drought occurs, the cities are the first to have limited water. We now rely completely on aqueduct water. One thing I would like to do is to begin collecting rain water. Because right now we are suffering a drought similar to the one we experienced a year and a half ago and all of our crops are going to die. So that is one of the changes to which we're currently vulnerable. (Huerto Semilla).

Organizational leaders who work specifically with urban gardening and agriculture in the city expressed similar concerns related to urbanization and drought. They have experimented with new horticultural methods to mitigate risk through plant seeds that may be able to resist extreme climate changes and have greater capacity for water retention. Other water resource management strategies described included the construction of garden ditches to manage flooding and the diversification of potable water sources. After Hurricane Maria, which made landfall on September 20, organizational leaders quickly learned how vital urban and organic gardening is a key practice for the survival of people on the island. As one organizational leader described:

After the hurricane everything was clean, so we replanted with the same care and strategy, the land returned in a way that was so fast that we lost the market on October $1^{\text {st }}$ and the $15^{\text {th }}$ of October we had 16 tables, and we banded together as organic agriculturalists, but the regular agriculturalist suffered a lot. (Coop Madre Tierra post-hurricane).

Organizations such as Coop Madre Tierra described how teaching the community about healthy living and organic farming techniques provided both much needed food for community residents and a source of income for agriculturalists. Puerto Rico was not prepared for such a devastating natural disaster, but the organic agricultural sector proved to be the strongest sector of the agricultural market because of their quick recovery and non-reliance on the external food market.

\section{Access to relevant information}

Environmental conservation organizational leaders indicated that a key component of mitigating flood risk in San Juan is to educate community members with appropriate materials. When organizational leaders were asked if enough information was available to community members on how to adapt and mitigate climate change and flooding, they stated that although the internet may provide a wealth of information, it is generally not presented in an accessible manner. Moreover, research studies are written by scientists for other scientists and it is difficult for community members to understand and put research results into practice. One organizational leader explained how her NGO is working to breakdown this knowledge barrier:

The information is available but it's not accessible. The information is written from peers for peers. It's not accessible to the community. It's not in graphics, it's not black and white. That's something that we try to do. Each investigation that we do, every workshop that we do has a lot of graphics, and designs that are easy to understand. Because it's the only way to disseminate education. You go to a community 
with a 20 page pamphlet, well, sorry but with as much work as it took, nobody is going to read it. But if you go with posters and graphs and numbers then that is understandable to anyone. So it's not the lack of information, it's the lack of design and accessibility of the information. (La Maraña).

Assisting communities in accessing information was an effort conducted by several of the organizations in this study. They argued that there is too much information online, and it is difficult to navigate and extract the necessary information to address issues at the community level. Therefore, they must take it upon themselves to develop creative strategies for providing information that is relevant and understandable to community members. While organizations in this study such as the San Juan Bay Estuary and La Maraña work to translate relevant data into more easily comprehended graphs, tables and icons, their resources are often limited, and community members struggle with how to adapt and apply research findings.

\section{Framing solutions to flood risk: structural versus nonstructural solutions}

Organizational leaders were asked about their perspectives on channelization of the Rio Piedras watershed (a structural solution) vs. the development of green spaces as a means to achieve flood control (non-structural solutions). We expected leaders to be strongly in support of green solutions to flooding and opposed to channelization given their organization's role in environmental conservation. While most leaders in this study did indeed tend to lean toward more green solutions to achieve flood control, our qualitative data revealed that perspectives toward these solutions are much more complex and nuanced than simply choosing channelization or green space solutions. Thus, although a few organizations did consistently oppose channelization, the majority of organizational leaders in this study argued that the watershed requires both channelization and green solutions to mitigate flooding.

Some participants recognized that several community members believe that channelization is a necessary means of preventing flooding, and while they may be personally against it, recognize that:

[...] most people prefer physical measures. The community sees water ways as a barrier to development. I don't think that it's an appropriate method, but I know that most people here do. (CAUCE).

Community leaders argue that with channelization, community members have given their backs to waterways and that water is often viewed as an adversary. They explained that parts of the river are already channelized and that flooding still occurs. Trash in the river continues to be a problem and blocks the flow of water creating more flooding. As one community leader who represents an area where the river is currently channelized explained:

The municipality has collaborated in trash pick up, and particularly after Maria they were coming every day, but then they only came once per week, and now they're only coming twice per month. But in terms of maintenance for the river, no, really nothing. I haven't seen anything and I've been here 7 years... where the river is, the walls of the canal have fallen, they fell years ago, and with Maria several trees fell and are on top of the walls, and those have not been picked up. (Huerto Capetillo posthurricane).

Other community leaders went on to explain that it is more important, and should be a higher priority to clean and dredge the river from debris and trash rather than invest in channelization. Nonetheless, both are necessary in order to mitigate flood risk in San Juan. Despite channalization's negative impact on flora and fauna, there are areas in the city that are already heavily urbanized and where channelization is viewed as a reasonable alternative. This more nuanced response including both channelization and green solutions to flooding was echoed by several other organizational leaders who indicated that they would have to study the context, i.e., morphological history, current infrastructure, and physical changes in the region before committing to support channelization efforts. Therefore, they argue: 
It all depends on whether there is a scientific study supporting it and research to show how it impacts the ecological systems of the natural environment. (Coop Madre Tierra).

Despite a recognition of channelization as a method for flood mitigation, all of the organizations in this study identified green area use as a more viable means for managing urban flooding. Several organizational leaders indicated that benefits associated with forestation have been documented, and that they would support any green area preventive or mitigation efforts to tackle risk due to climate change. However, due to lack of information about the benefits of green spaces, and water being viewed by community members as an adversary, the approach to green space development must include additional characteristics beyond flood mitigation. As one study participant stated:

In order for people to accept green spaces that reduce flooding, it needs to be sold to them as a way to reduce heat, have contact with nature, it's a nice place for the community to meet and hangout. (CAUCE).

For organizational leaders working with communities in the urban core, gaining support for green spaces is key because they see several opportunities to increase green area availability within the city, given the presence of vacant or abandoned lots that can serve as green pockets to increase flooding resilience. Turning vacant or abandoned lots into green areas for flood mitigation is a popular solution across all environmental conservation organizations. Similar to the city of Detroit, San Juan has experienced a 14.7\% population decrease during the period 2010-2017 (US Census Bureau, 2019), which has resulted in a multitude of vacant and abandoned lots throughout the city.

Throughout the interview process, a significant number of environmental conservation organizations consistently indicated opposition to channelization. They described the importance of not controlling river flows, and that water could be partially retained at green floodable locations. One interview participant described Portland, Oregon as an example of a location that has successfully used green infrastructure to manage flooding events, stating:

There are several models in the US that look at the problem of flooding through green space. The city of Portland, Oregon is an example where they have gardens in strategic areas for flood control and within the past five years they have been able to show that this type of gardening is effective for flood control. In other areas such as Hawaii, through both gardening and a type of planting, they have been able to purify rain water using different types of plants in order to control flooding. (Huerto Semilla).

While we expected to find opposition to channelization by environmental conservation organizations in this study, upon a more in-depth analysis of the data, we also found that consideration between structural versus non-structural solutions to flooding varied by age. The findings reveal that structural solutions tend to be considered as a more acceptable method of flood mitigation for older participants. For example, an older organizational leader interviewed shared a personal experience about frequent flooding at his home until a channelization project was built to successfully minimize occurrences:

Channelization provides results. Close to where I used to live, we had that problem of flooding, near the San Jose Lagoon we had that problem, and since they channelized it the problem ended. In a lot of areas of the city where it used to easily flood with rain, and today that's no longer the case because of channelization. It's very efficient in many areas, but there are areas where I will obviously be opposed to it because in some areas you have to leave it to nature, but humans always want to solve the problem without considering what will happen to the planet. (Playas Pa'l Pueblo).

In contrast, we found that all of the younger interview participants in this study consistently rejected structural solutions. All interview participants recognize the importance of non-structural solutions such as the development of green spaces.

Across all environmental conservation organizations, when asked about innovation and structural vs. non-structural solutions to decrease flood risk in the face of climate change, non-structural solutions were overwhelmingly prevalent when compared to structural solutions. Green area provision was consistently mentioned as playing a role in decreasing flooding events. Other solutions included dune 
formation, rain water collection, and building garden ditches. There is also a recognition of the presence of non-human species and how engineered solutions such as channelization have a direct impact on their survival. Most participants agreed on the importance of recognizing non-human species when considering climate related solutions for at risk communities.

Participants' age also seems to be a factor when considering strategies for effective community engagement and local problem solving. Older participants tend to assume public sector participation is necessary, and focused on the need to involve the government in community improvement projects. The community leadership was seen as an intermediary between residents and the government, or as in partnership with government and academia to solve problems. As one older interview participant described:

The example begins with the government. If the government doesn't help the people, educate the people about pollution then there will be people who don't know. (Parada 27/G-8).

In contrast, younger participants did not stress or emphasize the role of government, but rather focused on the need to solve community problems at the local level using local resources. If government was mentioned by this group, there was skepticism about their ability to assist communities in attaining their goals. One interview participant described his skepticism toward city government's role in assisting his community:

They build parks in a neighborhood but they don't ask people if they want that. The city builds spaces but they don't ask the people. The government has been building the city without any input from the people. A mayor comes in and thinks that it is a good idea and just builds without asking the people what they want. This is the way that San Juan has been built. (Huerto Capetillo).

\section{Institutional and procedural considerations: efforts to engage communities in alternative solutions to flood risk management}

Across all environmental conservation organizations, community engagement and education were consistently perceived as necessary for a more resilient and livable city in the face of extreme weather events. Some leaders described the importance of community centers to assist vulnerable communities and marginalized groups. Through a broad array of community groups and alliances across organizations, concerns can be gathered at the local level, channeling them to government offices, and local groups would act as intermediaries.

Some organizational leaders argue that to engage communities at the local level, it is imperative to understand the importance of information flows and effective community drivers of change. One organizational leader explained that having worked with communities with varied socio-economic profiles, she found that community engagement and education are key drivers of change. In other words, educating the community is critical to bridge resource gaps with action. Therefore, information flows were described by participants as more effective in communities with credible leaders who know how to educate and engage the community to identify resources that may be lacking. As one community leader argued:

It cannot come from the top. It needs to be bottom up, and to do something like this requires a lot of people, so we need to raise consciousness. To raise consciousness there needs to be community activities. (Coop Madre Tierra).

Organizational leaders went on to explain how some communities lack knowledge on how to mitigate for common climatic events related to coastal erosion and drought. Thus, government, academia and community partnerships would be especially useful in designing and implementing mitigation efforts. Moreover, in any mitigation and adaptation effort, community members should be involved from the beginning of the project. For example, community members can provide essential local knowledge to 
identify vulnerable areas due to flooding and assist in the implementation of mitigation actions in collaboration with academia and government agencies, both federal and local. Communities can be involved in monitoring impacts of climate change such as coastal erosion, and the effectiveness of mitigation efforts. After Hurricane Maria, communities were initially forced to take action on their own rather than expect assistance from the government. For example, one community leader explained how many clean-up efforts were spearheaded by the community:

Since the hurricane took place, the municipality took 30 days to come into the community. So the process of removing trash and debris was led by the community. They helped to bring in trucks to minimize the problem. (Parada 27/G-8 post-hurricane).

In sum, environmental conservation organizations see community participation as critical to achieving a more livable city with increasing resilience to flood risk. Communities are seen as the key to achieve long term sustainability. Their suggested management approach is bottom-up, using participatory techniques to understand community needs and problems.

\section{The role of flooding in defining city livability}

The term livability was not clearly understood by participants when conducting interviews. Some indicated the city was livable mainly because we live and are able to meet our basic needs in it, so their focus was usually on how to make the city more livable, not whether it was livable at the time of the interview. As opposed to other questions, it was when asked about livability that participants adopted a more general, holistic, and future oriented perspective when thinking of the impacts of climate change and flooding in San Juan. Thus, organizational leaders provided potential solutions to mitigate climate change impacts that would make the city more livable.

In terms of recommendations for future livability, interview participants who did engage the concept of livability more broadly mentioned the need for passive recreation spaces in the city, and the important role of green infrastructure projects. While these organizational leaders emphasized the social benefits of recreation services, others focused on carbon sequestration, oxygen production, and increased capacity to manage flooding events due to ground absorption capacity. For example, when one of these organizational leaders' was asked about whether San Juan is a livable city, he replied:

We need more recreation parks where families can come together with their children to practice ecology, gardens, and agricultural areas where people can learn to grow their own food. Green areas to educate the community to be more sustainable and manage water. And that is done when people are having fun. Build more parks, develop a moratorium where building will no longer take place in green areas, and reutilizing and rehabilitating several buildings that need revitalization... San Juan is beautiful and has a lot of characteristics like beautiful views, sun, a diversity of plants and land, it's very rich physically, geologically, and culturally. I believe that we should integrate all of that richness so that people can feel better and have a higher quality of life. (Coop Madre Tierra).

The importance of aesthetically pleasing green areas and development of green infrastructure that is built to filter the flow of water, was repeated throughout the interview process. Moreover, organizational leaders were pressed further on whether or not they currently perceive San Juan as -a livable city. One organizational leader then explained that a livable city is one where there is excellent community organization and a sense of belonging, and information flows are adequate for problem solving. However, the leader also described that San Juan communities were largely unaware of options when facing environmental risks. As a result, if a natural disaster were to happen, such as in the case of Hurricane Maria, we may likely see physical infrastructure losses as well as human losses. A more livable city was then described as one with lower economic losses due to deficient physical infrastructure and community displacement. 
In addition, organizational leaders argued that if San Juan were a livable city, the coast would no longer be seen as just a natural resource, but as a critical component of all infrastructure, blue, green and gray. It would be resilient to climate change and associated risks. Participants explained that in order to achieve these livability goals, there must be a change in current laws and regulations, particularly those referring to zoning and land use, to facilitate effective responses to extreme events. Nevertheless, the political arena is seen as a challenge to enacting changes in laws and regulations associated with climate change. In terms of paths to achieve desired solutions, participation at the community level was seen as necessary for successful implementation of risk reduction efforts.

The discussion on how to make cities more livable involved a consideration of a time scale component that should be considered; while answers about what makes San Juan a more livable city were future oriented, several respondents referred to past ways of living. They see in the past solutions for the present and future. As one organizational leader who lives in an area that has already been channelized described:

A lot of people think that before there was channelization that it was better, before it was channelized they used the river to fish, swim, and utilize it as part of their lives. Now the community has their backs to the river because it's closed off and there is no direct use for the community. Since the community does not use it, then they dump trash, and they don't respect it because they don't know it. (Huerto Capetillo).

While there is a sense of utilization of more sustainable practices and local past knowledge that we can learn from, discussions of livability were often framed in ideas of a more sustainable, perhaps romanticized past. There was no recognition of the implicit dynamic socio-demographic and economic context in constant evolution. Finally, when asked about livability in terms of risk related to climate change, organizational leaders expressed concern that San Juan was not ready for hurricanes, tsunamis or earthquakes, and that current infrastructure was lacking in this regard. Their perception of the state of infrastructure aligns with the collapse observed in the aftermath of Hurricane Maria.

\section{Conclusion}

Most organizational leaders consistently considered local non-structural solutions as the way forward to reduce flood risk, while some older participants still emphasized the role of government in seeking structural solutions to promote resilience in at risk communities in the San Juan area. While the development of sustainable practices at the local level with local resources is necessary, there are some regional and global scale issues that must also be considered as part of the sustainability agenda. Perhaps the broader scale and complexity of regional and global issues seem insurmountable, and the result can be generally ignoring the problem, or community members feeling a sense of helplessness about issues occurring at that scale.

There also needs to be a reconciliation between present visions of sustainability relying on past ideas and memories, perhaps idealized, and a vision more grounded on the current and future dynamic sociodemographic, economic, and post-hurricane context. Current livability ideals may imply lower urban population densities and more urban green area availability. While this may be achievable in some cases, and not necessarily incompatible with a sustainability agenda, green area strategy formulation at the community level would benefit from a multi-scalar consideration of problems and solutions. Green areas can still be part of the solution to diminish climate change and flood related risk and create a new path forward for recovering after Hurricane Maria, but must be pondered considering a dynamic sociodemographic context, such as changes in population and physical infrastructure needs at various scales.

Environmental conservation organizations have a key role to play, and have already proven successful at achieving concrete goals towards creating more livable and sustainable local spaces. If community action were to transcend local boundaries by means of appropriate coordination with other community organizations at the local and regional level, their scope of action would lead to a more sustainable urban 
environment. Emphasis should be placed on understanding the multiple ways in which communities understand the impacts of climate change and how they offer solutions to mitigation efforts. Bottom-up perspectives and approaches will potentially provide a more comprehensive, multi-dimensional, and multi-scalar urban development agenda that would explicitly manage flood risk, advancing livability and sustainability goals for coastal cities, and increase the likelihood of community members being included as stakeholders.

\section{References}

Ayyub, B. M., \& Wright, R. N. (2016). Adaptive climate risk control of sustainability and resilience for infrastructure systems. Journal of Geography \& Natural Disasters, 6(2), e118. http://dx.doi.org/10.4172/2167-0587.1000e118.

Balsas, C. (2004). Measuring livability of an urban centre: an exploratory of key performance indicators. Planning Practice and Research, 19(1), 101-110. http://dx.doi.org/10.1080/0269745042000246603.

Birkholz, S., Muro, M., Jeffrey, P., \& Smith, H. M. (2014). Rethinking the relationship between flood risk perception and flood management. The Science of the Total Environment, 478, 12-20.

http://dx.doi.org/10.1016/j.scitotenv.2014.01.061. PMid:24530580.

Bogdan, O. Z., Jan, A., \& Maurycy, C. (2018). Applying the theory of reliability to the assessment of hazard, risk and safety in a hydrologic system: a case study in the Upper Sola River Catchment, Poland. Water, 10(6), 723.

Center for Planning Excellence - CPE. (2015). The view from the coast: local perspectives and policy recommendations on Flood-Risk Reduction in South Louisiana. Baton Rouge: Center for Planning Excellence.

Conger, B. (2015). On livability, liveability and the limited utility of quality-of-life rankings. The School of Public Policy Publications, 7(4), 1-9.

Crichton, D. (1999). The risk triangle. In J. Ingleton (Ed.), Natural disaster management. London: Tudor Rose.

Di Baldassarre, G., Viglione, A., Carr, G., Kuil, L., Yan, K., Brandimarte, L., \& Blöschl, G. (2015). Debates: perspectives on socio-hydrology: capturing feedbacks between physical and social processes. Water Resources Research, 51(6), 4770-4781. http://dx.doi.org/10.1002/2014WR016416.

Fothergill, A., \& Peek, L. A. (2004). Poverty and disasters in the United States: a review of recent sociological findings. Natural Hazards, 32(1), 89-110. http://dx.doi.org/10.1023/B:NHAZ.0000026792.76181.d9.

Garau, C., \& Pavan, V. (2018). Evaluating urban quality: indicators and assessment tools for smart sustainable cities. Sustainability, 10(3), 575. http://dx.doi.org/10.3390/su10030575.

Gersonius, B., VanBuuren, A., Zethof, M., \& Kelder, E. (2016). Resilient flood risk strategies: institutional preconditions for implementation. Ecology and Society, 21(4), art28. http://dx.doi.org/10.5751/ES-08752210428.

Gough, M. (2015). Reconciling livability and sustainability: conceptual and practical implications for planning. Journal of Planning Education and Research, 35(2), 145-160. http://dx.doi.org/10.1177/0739456X15570320.

Hankins, K., \& Powers, E. (2009). The disappearance of the state from livable urban spaces. Antipode, 41(5), 845866. http://dx.doi.org/10.1111/j.1467-8330.2009.00699.x.

Holden, M. (2006). The World Urban Forum III: Vancouver. Cities, 23(3), 167-169.

http://dx.doi.org/10.1016/j.cities.2006.03.002.

Hong, C., \& Chung, E. (2016). Temporal variations of citizens' demands on flood damage mitigation, streamflow quantity and quality in the korean urban watershed. Sustainability, 8(4), 370.

http://dx.doi.org/10.3390/su8040370.

International Strategy for Disaster Reduction - ISDR. (2002). Guidelines for reducing flood losses. Geneva: United Nations International Strategy for Disaster Reduction (UNISDR). 
Jacobs, J. (1961). The life and death of great american cities. New York: Random House.

James, P. (2012). Our cities are us. Harvard International Review, 34(1), 34-39.

Joffe, H., \& Yardley, L. (2004). Content and thematic analysis. In D. F. Marks, \& L. Yardley (Eds.), Research methods for clinical and health psychology (pp. 56-68). London: Sage Publications.

Jukrkorn, N., Sachdev, H., \& Panya, O. (2014). Community-based flood risk management: lessons learned from the 2011 flood in central Thailand. WIT Transactions on Ecology and The Environment, 184, 75-86.

http://dx.doi.org/10.2495/FRIAR140071.

Kashef, M. (2016). Urban livability across disciplinary and professional boundaries. Frontiers of Architectural Research, 5(2), 239-253. http://dx.doi.org/10.1016/j.foar.2016.03.003.

Konrad, C. (2016). Effects of urban development on floods (U.S. Geological Survey Fact Sheet; Vol. 076-03). Reston: U.S. Geological Survey.

Kryzanowski, A., Brilly, M., Rusjan, S., \& Schnabl, A. (2014). Review Article: structural flood-protection measures referring to several European case studies. Natural Hazards and Earth System Sciences, 14(1), 135-142.

http://dx.doi.org/10.5194/nhess-14-135-2014.

Liquete, C., Kleeschulte, S., Dige, G., Maes, J., Grizzetti, B., Olah, B., \& Zulian, G. (2015). Mapping green infrastructure based on ecosystem services and ecological networks: a Pan-European case study. Environmental Science \& Policy, 54, 268-280. http://dx.doi.org/10.1016/j.envsci.2015.07.009.

Low, M. (2013). Eco-cities in Japan: past and future. Journal of Urban Technology, 20(1), 7-22.

http://dx.doi.org/10.1080/10630732.2012.735107.

McEwen, L., Garde-Hansen, J., Holmes, A., Jones, O., \& Krause, F. (2017). Sustainable flood memories, lay knowledges and the development of community resilience to future flood risk. Transactions of the Institute of British Geographers, 42(1), 14-28.

Meléndez-Ackerman, E., Nytch, C., Santiago-Acevedo, L., Verdejo-Ortiz, J., Santiago-Bartolomei, R., Ramos-Santiago, L., \& Muñoz-Erickson, T. (2016). Synthesis of household yard area dynamics in the city of San Juan multi-scalar social-ecological perspectives. Sustainability, 8(5), 241. http://dx.doi.org/10.3390/su8050481.

Muñoz-Erickson, T. A. (2014a). Co-production of Knowledge-action Systems in Urban Sustainable Governance: the KASA approach. Environmental Science \& Policy, 37, 182-191. http://dx.doi.org/10.1016/j.envsci.2013.09.014.

Muñoz-Erickson, T. A. (2014b). Multiple pathways to sustainability in the city: the case of San Juan, Puerto Rico. Ecology and Society, 19(3), 2. http://dx.doi.org/10.5751/ES-06457-190302.

Muñoz-Erickson, T. A., Campbell, L. K., Childers, D. L., Grove, J. M., Iwaniec, D. M., Pickett, S. T. A., Romolini, M., \& Svendsen, E. S. (2016). Demystifying governance and its role for transitions in urban social-ecological systems. Ecosphere, 7(11), e01564. http://dx.doi.org/10.1002/ecs2.1564.

Muñoz-Erickson, T. A., Lugo, A., \& Quintero, B. (2014). Emerging synthesis themes from the study of socialecological systems of a tropical city. Ecology and Society, 19(3), art23. http://dx.doi.org/10.5751/ES-06385190323.

Pasch, R. J., Penny, A. B., \& Berg, R. (2018). National Hurricane Center Tropical Cyclone Report: Hurricane Maria (AL152017). Washington: National Oceanic and Atmospheric and Administration, National Weather Service. Retrieved in 2019, June 18, from https://www.nhc.noaa.gov/data/tcr/AL152017_Maria.pdf

Perkins, N. D. (2008). Livability, regional equity, and capability: closing in on sustainable land use. University of Baltimore Law Review, 37(2), 157-202.

Razafindrabe, B., Kada, H., Arima, N., \& Inoue, R. (2014). Analyzing flood risk and related impacts to urban communities in central Vietnam. Mitigation and Adaptation Strategies for Global Change, 19(2), 177-198. http://dx.doi.org/10.1007/s11027-012-9433-z. 
Reinhardt, L., Jerolmack, D., Cardinale, B., Vanacker, V., \& Wright, J. (2010). Dynamic interactions of life and its landscape: feedbacks at the interface of geomorphology and ecology. Earth Surface Processes and Landforms, 35(1), 78-101. http://dx.doi.org/10.1002/esp.1912.

Ruth, M., \& Franklin, R. (2014). Livability for all? Conceptual limits and practical implications. Applied Geography, 49, 18-23. http://dx.doi.org/10.1016/j.apgeog.2013.09.018. PMid:25339785.

Santiago, L., Gladkikh, T., Betancourt, L., \& Vargas, Y. (2015). Green versus gray: attitudes toward vegetation in a tropical metropolitan square. Environment and Natural Resources Research, 5(2), 109-120. http://dx.doi.org/10.5539/enrr.v5n2p109.

Schneiderbauer, S., \& Ehrlich, D. (2004). Risk, hazard and peoples' vulnerability to natural hazards: a review of definitions, concepts and data. Brussels: EC JRC.

Shan, M., Hwang, B., \& Zhu, L. (2017). A global review of sustainable construction project financing: policies, practices, and research efforts. Sustainability, 9(12), 2347. http://dx.doi.org/10.3390/su9122347.

Silverstein, N., Johns, E., \& Griffin, J. (2008). Students explore livable communities. Gerontology \& Geriatrics Education, 29(1), 19-37. http://dx.doi.org/10.1080/02701960802074248. PMid:19042225.

Slovic, P. (1987). Perception of risk. Science, 17(4799), 236-280. PMid:3563507.

Sun, D., Zhang, D., \& Cheng, X. (2012). Framework of national non-structural measures for flash flood disaster prevention in China. Water, 4(1), 272-282. http://dx.doi.org/10.3390/w4010272.

Sutton-Grier, A. E., Gittman, R. K., Arkema, K. K., Bennett, R. O., Benoit, J., Blitch, S., Burks-Copes, K. A., Colden, A., Dausman, A., DeAngelis, B. M., Hughes, A. R., Scyphers, S. B., \& Grabowski, J. H. (2018). Investing in natural and nature-based infrastructure: building better along our coasts. Sustainability, 10(2), 1-11.

http://dx.doi.org/10.3390/su10020523.

Tierney, K. (2014). The social roots of risk: producing disasters, promoting resilience. Stanford: Stanford University Press.

Tullos, D. (2018). How to achieve better flood-risk governance in the United States. Proceedings of the National Academy of Sciences of the United States, 115(15), 3731-3734. http://dx.doi.org/10.1073/pnas.1722412115. PMid:29636426.

Uehara, M. (2017). Individual risk perception and flood mitigation: an empirical study of protective actions in australia (PhD thesis). University of Queensland, St. Lucia.

US Army Corps of Engineers - USACE. (2015). Use of natural and nature-based features (NNBF) for coastal resilience. New York: USACE.

US Army Corps of Engineers - USACE. (2017). Flood risk management general reevaluation report \& environmental impact statement for the Village of Mamaroneck \& Sheldrake river basins: final report. New York: USACE.

US Census Bureau. (2019). Quick facts. Retrieved in 2019, June 18, from https://www.census.gov/quickfacts/sanjuanmunicipiopuertorico

Wheeler, S. (2001). Planning sustainable and livable cities. In R. LeGates, \& F. Stout (Eds.), The city reader. (3rd ed., pp. 486-496). London: Routledge. Original work published 1998.

Editor: Harry Bollmann

Received: June 18, 2019

Approved: Aug. 29, 2019 